\title{
Optimization and improvement of the goods loading process in the transportation units
}

\section{Optimización y mejora del proceso de carga de mercancías en las unidades de trasporte}

\author{
BENÍTEZ-LÓPEZ, Guillermo†** \\ Academic Department of Logistics Engineering, Instituto Tecnológico Superior de Naranjos, Guanajuato S/N, Colonia \\ Manuel Ávila Camacho. C.P. 92370, Naranjos, Veracruz. México
}

ID $1^{\text {st }}$ Author: Guillermo, Benítez-López / ORC ID: 0000-0003-2006-9876, CVU CONACYT ID: 468967

DOI: $10.35429 / J B D S .2021 .20 .7 .1 .9$

Received September 03, 2021; Accepted November 30, 2021

\begin{abstract}
This research work was carried out with the objective of optimizing and improving the process of loading the goods transported in a commercial company of industrial products, where it was required to diagnose the area of shipments or departures, pointing out the current problems of the company through from an Ishikawa diagram, Later the stages of the loading process were identified by taking and recording the times taken, Likewise; The items with the highest turnover and their characteristics were recorded, by reviewing historical loads, proceeding to the taking and recording of volumetric dimensions measurement in the; load units, to the packaging or boxes and wooden pallets with the support of a flexometer and the use of Hopewell Autocube 8200 (Volumetric measurements), through the use of AutoCAD some load simulations were carried out, comparing and identifying the empty spaces that They were left due to poor arrangement, managing to optimize them by increasing the amount of cargo and thus preventing the goods handled from being damaged during transport, in addition, an improvement was obtained in the completion times of the stages of the registered process under constant supervision.
\end{abstract}

AutoCAD, Improvement, Optimization

\begin{abstract}
Este trabajo de investigación se realizó con el objetivo de optimizar y mejorar el proceso de carga de las mercancías transportadas en una empresa comercializadora de productos industriales, donde se requirió diagnosticar el área de embarques o de salidas, señalando la problemática actual de la empresa a través de un diagrama de Ishikawa, Posteriormente se identificaron las etapas del proceso de carga tomando y registrando los tiempos realizados, Así mismo; se registraron los artículos de mayor rotación y sus características, mediante la revisión de cargas históricas, procediendo a la toma y registro de medición de dimensiones volumétricas en las; unidades de carga, a los embalajes o cajas y pallets de madera con el apoyo de un flexometro y el uso de Hopewell Autocube 8200 ( Medidas volumétricas), mediante el uso de AutoCAD se realizaron algunas simulaciones de carga, comparando e identificando los espacios vacíos que dejaban por el mal acomodo, logrando optimizarlos incrementando la cantidad de carga y evitando así que la mercancía manejada sufriera daños durante el transporte, además se obtuvo una mejora en los tiempos de realización de las etapas del proceso registrado bajo una supervisión constante.
\end{abstract}

AutoCAD, Mejora, Optimización

Citation: BENÍTEZ-LÓPEZ, Guillermo. Optimization and improvement of the goods loading process in the transportation units. Journal of Business Development Strategies. 2021, 7-20: 1-9

\footnotetext{
* Correspondence to Author (email: guillermo.benitez@itsna.edu.mx)

$\dagger$ Researcher contributing first author
} 


\section{Introduction}

The optimization and improvement of current processes within supply chains are extremely necessary to speed up product deliveries on time to the final consumer, this being the most important objective in any type of company; That is why it is important to pay attention to the activities of loading goods within the transport units since it is necessary to pay special attention to the arrangement of the pallets or pallets, the type of goods, type of cargo and the route that they will carry, and so; To be able to make the most of all the capacity of the unit, in reference to the regulations and vehicle capacity, when we carry out a weak and deficient load, we would be affecting the operating cost of all those involved in the process.

A load unit must use its maximum capacity, On the other hand, the supervision of the process and a good arrangement and maneuvering of goods in the units within the units, is decisive for the personnel in charge of this process, since delivery times are speeded up and contributes to having a better distribution of the goods. Within the units. Understand the importance that this activity represents for the correct functioning of the transport of goods according to its capacity. (Guzman, GC, \& Serrato, RB 2018, p.13). The proposed solution was to carry out a, review of the stages of the process of loading goods to transport units to optimize and improve it.

Therefore, we proceeded to review the process and the stages involved in it in the shipping or departure area, observing that empty spaces were left when finishing it, this could cause damage to the products when being transported, a logistics process It is made up of a series of stages, which occurin a chain and depend, on the one hand, on the nature of the product itself and, on the other, on the main activity of the company. (Escudero Serrano, MJ 2019, p.3).

Considering that the capacity of the units could be used to accommodate more boxes within the unit, so we began with the taking and recording of times in the realization of this process, the products that show the highest turnover in the company and their characteristics, through a review of the historical information in the previous shipping sheets.
That is why cargo transportation services are oriented to comply with the parameters and times that current markets demand, based on operations based on Logistics that streamline processes. (Soto Correa, HA, \& Rivadeneira Naranjo, NY 2019, p.3). Once these elements were established, the volumetric measurement of both internal and external load units was carried out, as well as; of the boxes and pallets used to accommodate customer orders within them, with the support of a flexometer and the Honeywell Autocube 8200 tool, which is a scanning software to obtain volumetric measurements. The current design of the analyzed products, comparing them with a redesign proposal, has a positive economic impact on the process, optimizing the cubic capacity in transport and the competitiveness of the company. Jiménez Castillo, J., et.al. (2015).

A large percentage of the areas involved in the transport of goods are an essential part of the logistics chain, these present incidents at the time of being executed, in most cases. Oleas(Lara, CX, et.al, (2020). 6 (3), 756-773. The cost structure, reference of road freight transport and the characteristics of the different road freight service providers contribute to improving the logistical processes of companies. (Ferrer, M., Ariza, Y., et.al. (2019). The previous step when acquiring a product is supplying it until it reaches the place of distribution. This process is determined by the supply chain that is defined as a set of processes necessary to satisfy the demand from the supply of raw materials, semifinished products, from their origin to their destination. (González, MJS 2018. p. 16).

Globalization is changing the way distribution companies relate to manufacturers and this in turn demands modifications to their internal processes that relate to their customers. That is why it is essential to invest in resources that allow remote assistance, train staff with resources that allow them to communicate with their customers remotely. (Laza, CA, 2019, p. 8). The company Proveedora de Seguridad Industrial del Golfo SA de CV, dedicated to the commercialization of industrial products in its process of loading goods within the units, it is an important aspect that we must not overlook and that by not making the most of the total capacity of the unit destined for it. 
It could generate unnecessary costs, so some simulations with the information collected and with the support of AutoCAD software and thus achieve a better arrangement of boxes and pallets, reducing empty spaces and increasing the load by $14 \%$ of its capacity and improving the times of completion of the stages of the process under supervision with a reduction of $21 \%$ in the time used for its realization, improving with this; customer service and company operating costs.

\section{Description of the Method}

\subsection{Diagnosis of the Departures or Departures area}

To carry out this research project it was necessary to establish a series of steps in order to reach its objective, which are detailed below:

An Ishikawa diagram was applied in the identification of the problem in the area of shipments or departures of the goods, considering four aspects involved in the process of loading goods: assortment, method, staff and supervisionBy identifying the causes and their impact on the company, this results in the poor arrangement of the pallets or pallets, the packaging (boxes) used in the loading units and as a consequence; the realization of a slow process, empty spaces inside the loading unit, and not counting that the personnel in charge of carrying it out is not supervised in their process and they are unaware of some important aspects such as; the volumetric measurements of the materials involved, shapes and weight of both the goods and the load units, wasting $100 \%$ of the capacity of the transport units to send the orders, as we can see in the figure one.

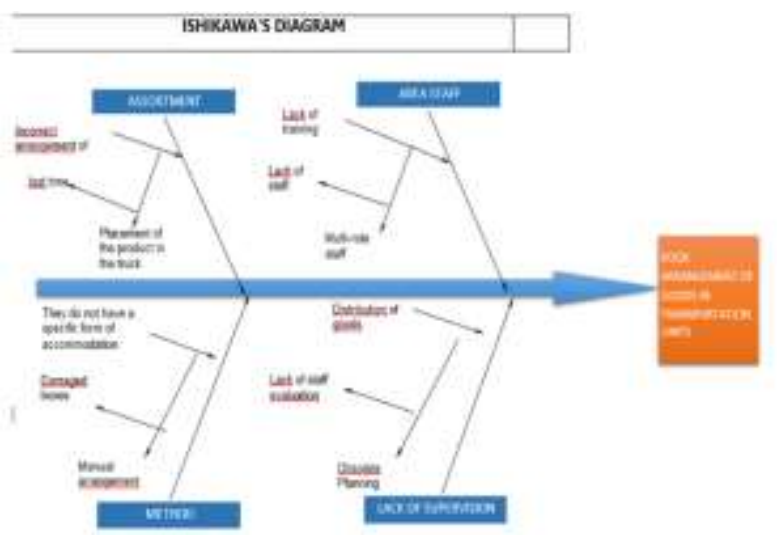

Figure 1 Diagnosis of the Departures or Departures area Source: Self Made

\subsection{Measurement of times to carry out the preparation for the loading of goods}

In the area of shipments or departures, the way in which the personnel involved in this Process were inspected, where the times used in each of the stages that involve the process of loading the goods in the units were taken and recorded; From the preparation of orders (Picking), the authorization of the same, the palletization, the Emplayado and the arrangement of the packaging or boxes within the unit, the way of placing both the boxes on the pallets or pallets and distribute them was considered within the load units, as seen in the table one, where the times obtained for each activity are shown.

\begin{tabular}{|l|l|}
\hline \multicolumn{1}{|c|}{ Stage of the process } & \multicolumn{1}{c|}{ Time to be done } \\
\hline 1. Picking & 5 hours \\
\hline 2. Picking authorization & 5 minutes \\
\hline 3. Palletizing & $20-30$ minutes. \\
\hline 4. Emplayado & $15-20$ minutes. \\
\hline $\begin{array}{l}\text { 1. Arrangement of goods in } \\
\text { cargo } \\
\text { units }\end{array}$ & $50-60$ minutes. \\
\hline $\begin{array}{l}\text { Total Time to Perform } \\
\text { minutes }\end{array}$ \\
\hline
\end{tabular}

Table 1 Record of times carried out in the Stages of the Preparation Process for the loading of goods Source: Self Made

These data will be necessary to make a comparison at the end of it since as we can see, the total time for the accommodation of goods without supervision in a Charging unit is 6 hours with 55 minutes estimated on average, we observe that the hours dedicated to this process is somewhat slow since it is not reviewed or verified by the company and this coupled with the ignorance of the volume dimensions of each charging unit, it can generate a bad arrangement of these and leave empty spaces on the part of the personnel who carry it out, this is one of the most common logistical problems in this type of activity.

\subsection{Identification of the goods with the highest turnover in the company}

An identification of the items with the highest turnover within the company's operations was carried out in order to identify their characteristics and verify if the packaging used is correct for this, for which two types of boxes of different sizes were documented. both large, medium and small, the latter with less turnover and that were not considered for this research due to their low relevance. 
As we can see in the table two, the products with the highest turnover and their characteristics were registered.

\begin{tabular}{|c|l|l|}
\hline No. & Name of Product & Features \\
\hline 1 & $3 \mathrm{~m}$ N95 Respirator & Disposable P / Powder. \\
\hline 2 & $3 \mathrm{~m}$ Respirator & P / Vapores Organicos S.. \\
\hline 3 & Cartridge 3m & 6000 Series For Steamers \\
\hline 4 & Girdle Vallen 2500 & Or W / Third Belt.. \\
\hline 5 & Overol Dupont Tyvek & C / Hood And Ela. \\
\hline 6 & Headband Barricade & Standard Ama \\
\hline 7 & Vallen 40h Boot & Brown C / C Steel Sole. \\
\hline 8 & Facial Mica Vallen & Universal Clear. \\
\hline 9 & Filter 3m N95 & P / Particles And Neblin. \\
\hline
\end{tabular}

Table 2 Goods with the highest turnover and their characteristics

Source: Self Made

When questioning the personnel in charge of this Process if they knew the characteristics of the goods that were in the boxes or packaging, they argued that at they did not. For this reason, we consider it important that the personnel involved in this type of process must know the characteristics of the products they handle in order to consider the maneuvering measures that will be given to them when loading them into the unit destined for their transport.

\subsection{Measurement of the internal and external dimensions of the load units}

The types of units that the company uses to carry out the goods dispatch process are single axle trucks with a load capacity of three tons. By considering the characteristics of these units, the types of packaging used for the goods and the characteristics of these, we can have a clearer idea of a better arrangement of these, as shown in the figures two, and the table three where the type of unit, volumetric capacity, load capacity, length, width and height of the unit are recorded.

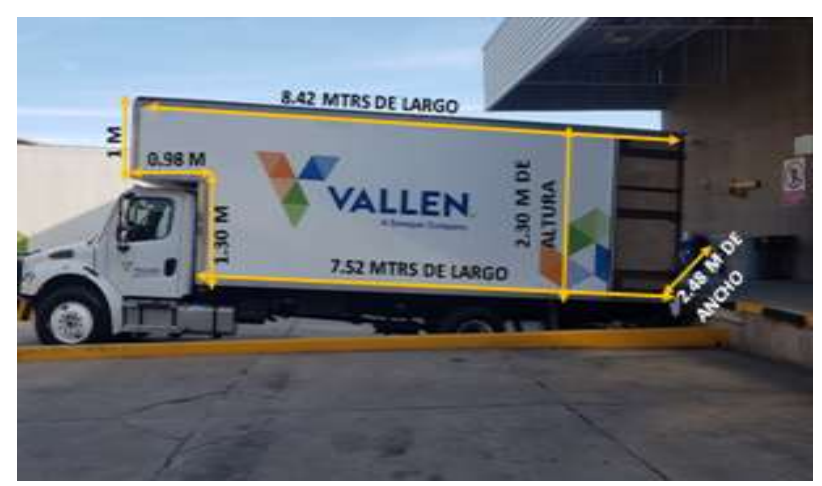

Figura 2 Image of the external dimensions of the Load Unit

Source: Self Made

\begin{tabular}{|l|l|l|l|l|l|}
\hline $\begin{array}{l}\text { Load } \\
\text { Units }\end{array}$ & \multicolumn{1}{c|}{$\begin{array}{c}\text { Volume } \\
\text { Capacity }\end{array}$} & \multicolumn{1}{c|}{$\begin{array}{c}\text { Load } \\
\text { Capacity }\end{array}$} & \multicolumn{1}{c|}{ length } & Width & Heigth \\
\hline $\begin{array}{l}\text { Single } \\
\text { Axle } \\
\text { Truck }\end{array}$ & M3 & 3 Ton. & $7.52 \mathrm{~m}$ & $2.48 \mathrm{~m}$ & $2.30 \mathrm{~m}$ \\
\hline
\end{tabular}

Table 3 External dimensions of the unit and load capacity Source: Self Made

As indicated in the previous point, ignorance of the type of goods that are handled in this type of maneuver can result in a bad arrangement of the boxes and cause damage to them during their transportation, as shown in the figure three.

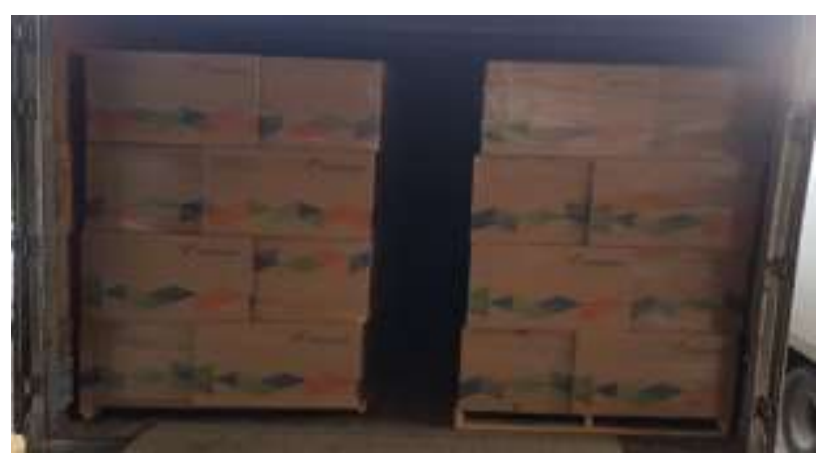

Figure 3 Image of unit loading with the above process Source: Self Made

\begin{tabular}{|c|c|c|c|c|c|}
\hline $\begin{array}{l}\text { Load } \\
\text { Units }\end{array}$ & $\begin{array}{l}\text { Volume } \\
\text { Capacity }\end{array}$ & $\begin{array}{c}\text { Load } \\
\text { Capacity }\end{array}$ & length & Width & Heigth \\
\hline $\begin{array}{l}\text { Single } \\
\text { Axle } \\
\text { Truck }\end{array}$ & M3 & 3 ton. & $7.52 \mathrm{~m}$ & $2.14 \mathrm{~m}$ & $2.13 \mathrm{~m}$ \\
\hline
\end{tabular}

Table 4 Internal dimensions of the unit and load capacity Source: Self Made

That is why the record of the internal dimensions was made considering also the volumetric capacity, load capacity, length, width and height of the units used to transport the goods as shown in the table four, and make these data known to the personnel in charge of the process, since it is very important to have knowledge of these references when loading a unit.

\subsection{Volumetric measurement of packaging (Boxes) and pallets}

It is not only necessary to know the dimensions of the load units, but also of the other elements used to load the goods, such as pallets or pallets and boxes or packaging as shown in the figure four. 
The empty pallets were also registered and with load as I know show in the tables five and six for this with we support the help of a flexometer and the Honeywell 8200 software that helped us to corroborate the measurements obtained and recorded both for taking measurements of the boxes and the pallets or pallets that are used in the process of loading goods in the unit and that were also made known to the staff involved in it.

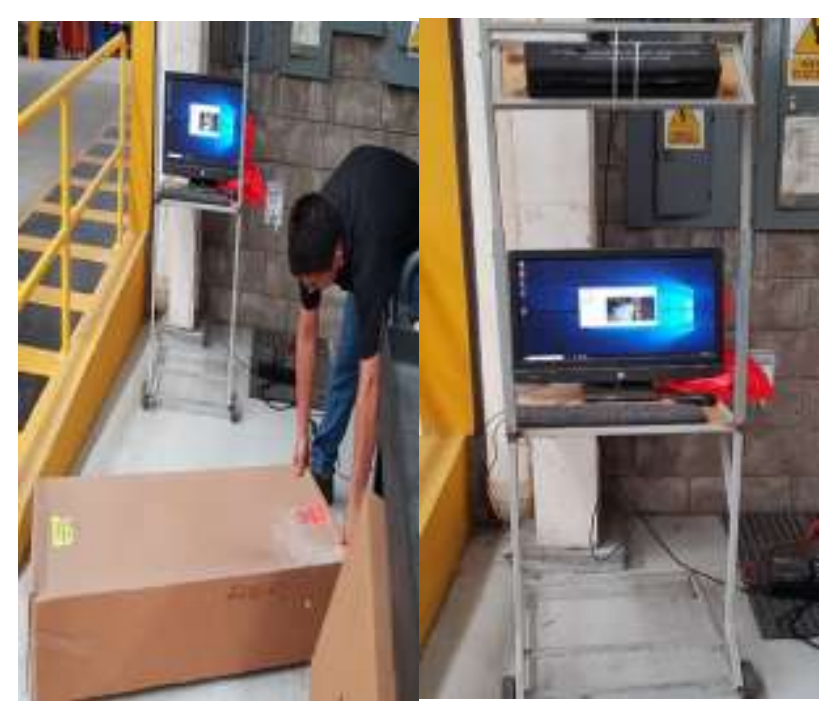

Figure 4 Image of the measurement of the dimensions of the boxes that are handled for the orders

Source: Self Made

Regarding the weight of the wooden pallets or pallets that are handled in the company, their weights range between $25 \mathrm{kgs}$, and they support loads of up to $1,500 \mathrm{kgs}$, each of them.

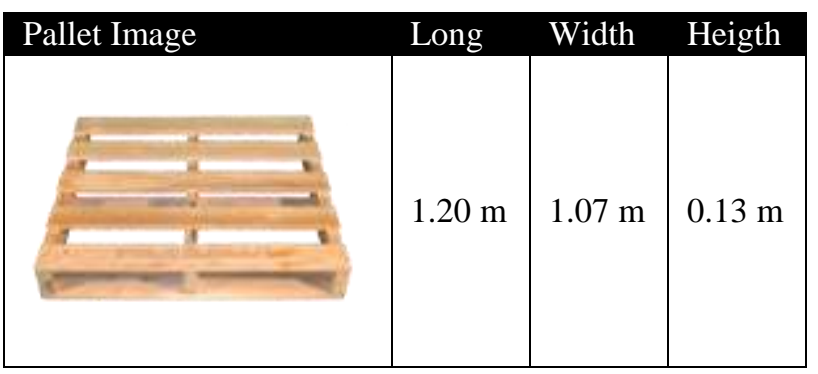

Table 5 Dimensions of the empty pallet or pallet Source: Self Made

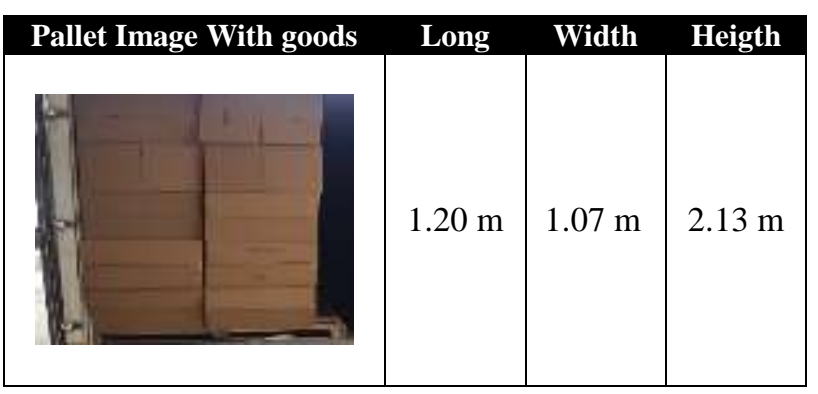

Table 6 Dimensions of the Pallet or Platform with goods Source: Self Made

ISSN 2444-4960

ECORFAN® All rights reserved
This company, dedicated to the sale of industrial security products, as mentioned above, handles two types of packaging or boxes, one of medium size with weight approximately 100 grams, and another large size with a weight of 200 grams, registering its data with the following characteristics such as: the long, width and height, of the same to identify their accommodation within the unit, as can be seen in the tables seven and eight, the order area (Picking) is in charge of placing the various goods requested by customers and once this operation is completed they are placed on the pallets or pallets to be packed and later placed inside the loading unit with the help of small lift truck.

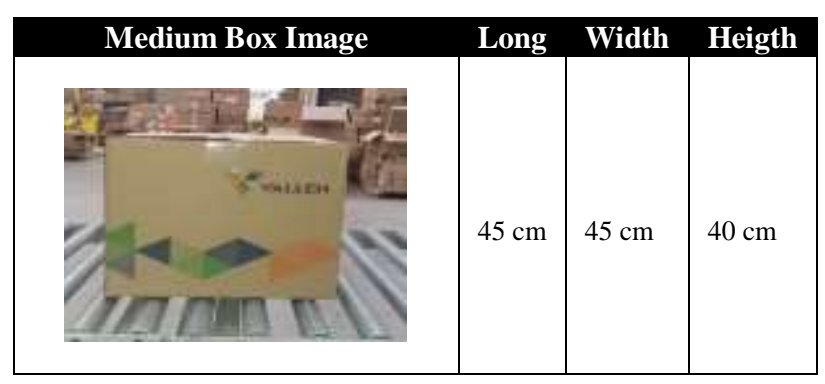

Table 7 Medium box dimensions Source: Self Made

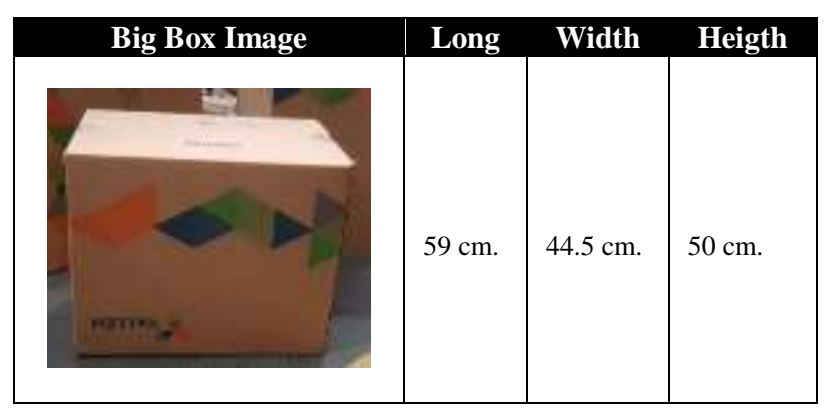

Table 8 Big box dimensions Source: Self Made

\section{Results}

Once the information that was considered necessary to develop this research was known and registered, some simulations of the process were carried out using the AutoCAD tool, achieving graphic representations of the arrangement of pallets or pallets and the goods within the load unit, first evidencing the process that they normally carry out to later propose another type of accommodation until it manages to reduce the empty spaces that were left with the previous process as shown in the figures five and six. 


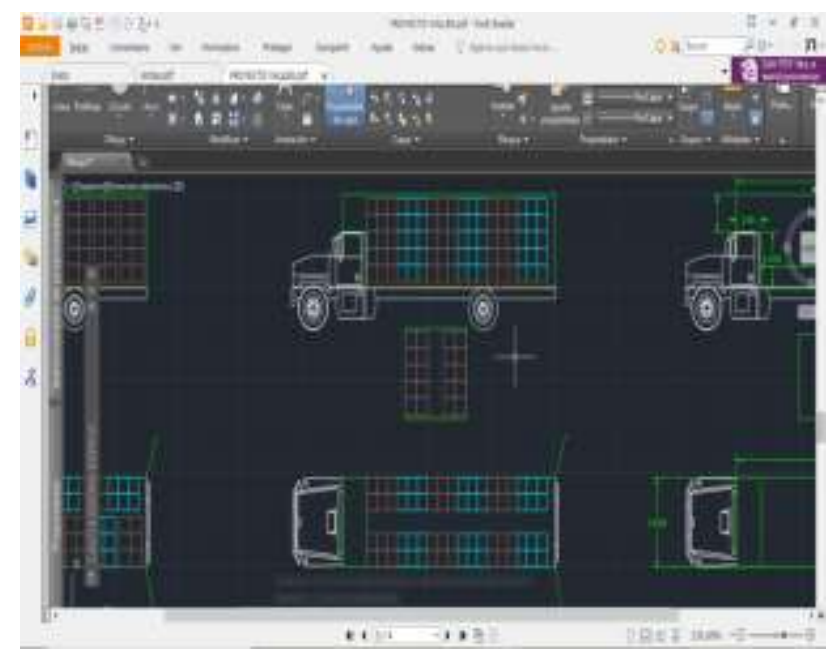

Figure 5 Simulation of normal palletizing within the unit by the personnel of the area

Source: Self Made

In this simulation we can observe the empty spaces that were left with the accommodation of the pallets or pallets in the previous loading process inside the unit. $45 \mathrm{~cm}$ $45 \mathrm{~cm} 40 \mathrm{~cm}$ for the following simulation shown in the figure six, a new rearrangement of the pallets or pallets within the unit is proposed considering the volumetric measurements obtained from the resources involved in the process.

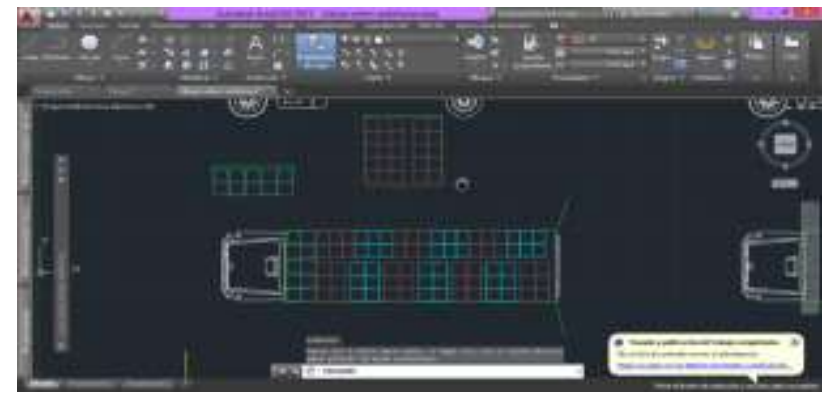

Figure 6 Simulation of the proposed arrangement of the palletization within the load unit Source: Self Made

As can be seen in this graphic image, with this proposal it was possible to achieve a better arrangement of the pallets, mostly reducing the empty spaces that were left in the previous process.

An example of inadequate arrangement of pallets or pallets with goods inside the load unit, can be seen in the following image of the figure seven, where the size of the empty spaces that remain as a result of a poor distribution in the normal process that the company staff handles are shown.

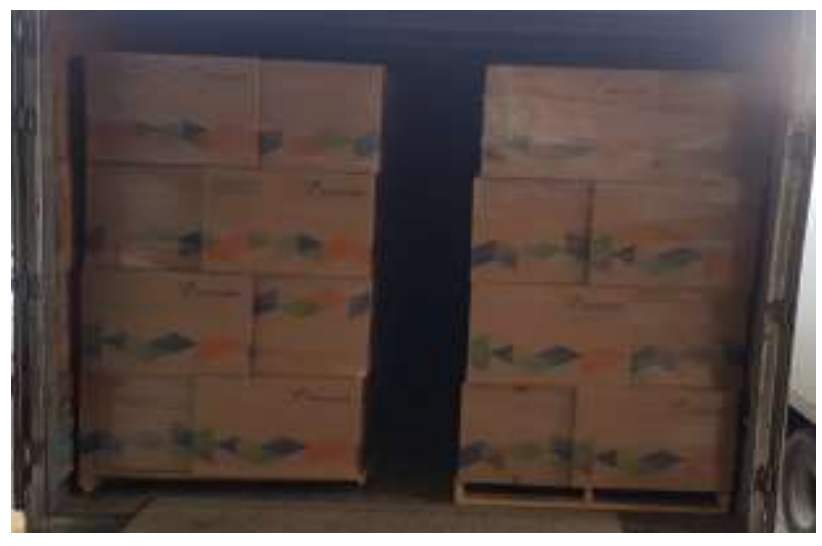

Figure 7 Image of the normal arrangement of boxes in the company's cubing process

Source: Self Made

In a new simulation, the packaging or boxes were arranged with the goods inside the unit as shown in the figure eight.

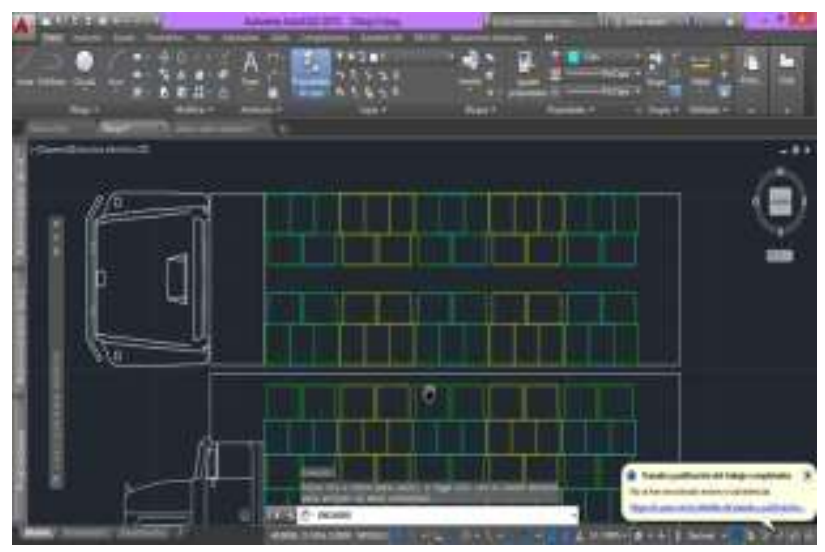

Figure 8 Simulation of the normal arrangement of boxes by the company within the load unit

Source: Self Made

This inappropriate distribution is the result of a process being carried out without supervision by the personnel in charge of the process.

In this last simulation, shown in the image of the figure nine, a different and recommended distribution of the boxes is proposed since the reduction of empty spaces is noticeable and a greater number of these can be placed inside the unit. 


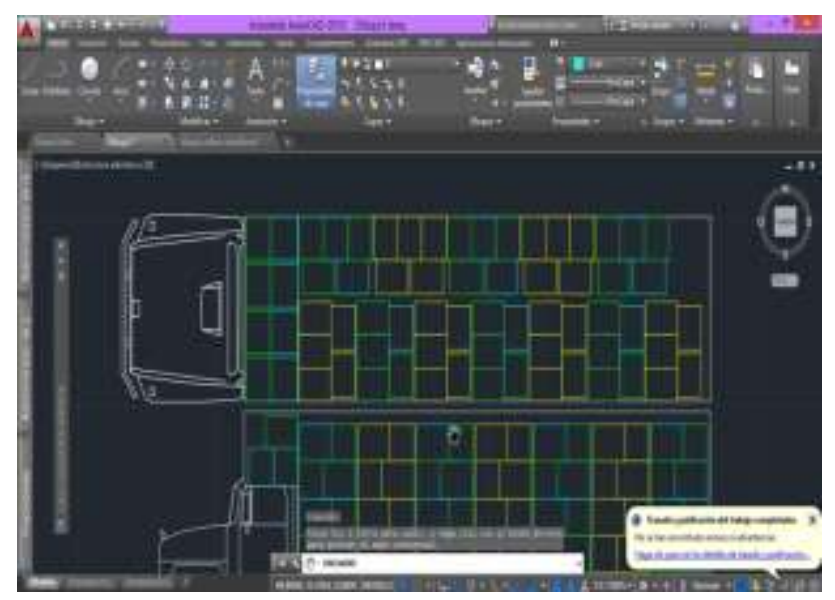

Figure 9 Simulation of the proper arrangement of boxes within the load unit

Source: Self Made

In the figure ten, we can see in the image the result obtained with the proposal of the new suggested arrangement within the load unit, achieving the reduction of empty spaces, thus achieving the introduction of a greater number of boxes, making the most of the load capacity.

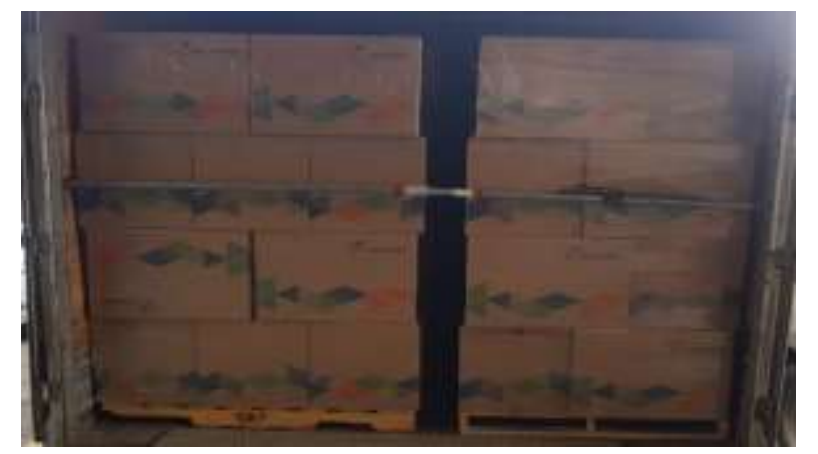

Figure 10 Image with the correct arrangement of the cubic capacity in the load unit

Source: Self Made

It was previously mentioned that by using the positioning simulations in AutoCAD, it was possible to achieve a better distribution of the pallets or pallets and the packaging or boxes used by the company for this process.

In the Table nine, the load capacity of the unit, its measurements and a comparison of the number of packages or boxes loaded inside the unit and the increase achieved with the proposed new distribution are shown.

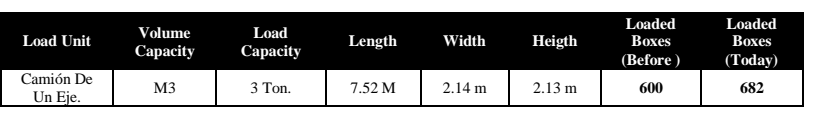

Table 9 Comparison of the load capacity used in the unit Source: Self Made
As we can see, the load capacity with the previous process was 600 units and with the new distribution it increased to 680 boxes, managing to place 82 more inside the unit. This represents $14 \%$ more load taking advantage of the total capacity of the unit.

And finally, the measurement and recording of times was carried out again in the stages of the process of loading the goods to the unit, with the suggestion that the process be carried out under supervision to corroborate whether or not there were improvements in the realization of this. . Applying the suggested recommendations, the following data was obtained, which is shown in the Table ten.

\begin{tabular}{|c|c|}
\hline Stages of Process. & Time to Be Done \\
\hline 1. Picking & 5 hours \\
\hline 2. Picking authorization & 5 minutes \\
\hline 3. Palletizing & $20-30$ minutes. \\
\hline 4. Emplayado & 15- 20 minutes. \\
\hline $\begin{array}{l}\text { 1. Arrangement of goods in cargo } \\
\text { 2. units }\end{array}$ & $50-60$ minutes \\
\hline Total Time Spend & 6 hours 55 minutes \\
\hline
\end{tabular}

Table 10 Record of times carried out in the Stages of the Preparation Process for the loading of goods Source: Self Made

Once these data were obtained and recorded, they were compared with results obtained in the times recorded in the preparation stages for loading without supervision in the Table one, and those achieved with the supervision suggested in the table ten, and the results are shown in the following Table eleven.

\begin{tabular}{|l|l|l|}
\hline \multicolumn{1}{|c|}{$\begin{array}{c}\text { Stages of the } \\
\text { process }\end{array}$} & \multicolumn{1}{c|}{$\begin{array}{c}\text { Previus Time } \\
\text { Registered }\end{array}$} & \multicolumn{1}{c|}{$\begin{array}{c}\text { Rurrent Time } \\
\text { Recorded }\end{array}$} \\
\hline Picking & 5 hours & 4 hours \\
\hline $\begin{array}{l}\text { Picking } \\
\text { authorization. }\end{array}$ & 5 minutes & 5 minutes \\
\hline Palletizing. & 30 minutes & 15 minutes \\
\hline Emplayado. of & 20 minutes & 10 minutes \\
\hline $\begin{array}{l}\text { Arrangement } \\
\text { merchandise } \\
\text { METRI in cargo } \\
\text { units. }\end{array}$ & 45 minutes \\
\hline $\begin{array}{l}\text { Total Time Spent } \\
\text { Time difference }\end{array}$ & $\begin{array}{l}\text { hours } 55 \\
\text { minutes }\end{array}$ & $\begin{array}{l}5 \\
\text { minutes. }\end{array}$ \\
\hline
\end{tabular}

Table 11 Comparison of Times Taken in the stages of preparation for loading goods

Source: Self Made 
In this final comparison of the times recorded for the completion of the process stages involved in the loading of goods in the units with and without supervision, it was possible to realize that from the stage of order preparation to the loading of these in the units cargo, the personnel in charge, were more agile when carrying it out; achieving an optimization of times of 1 hour 40 minutes with respect to those registered at the beginning of our investigation.

\section{Thanks}

We are grateful to the company Proveedora de Seguridad Industrial del Golfo SA de CV from Tampico, Tamaulipas, for the facilities granted to carry out this study within its facilities and to the Instituto Tecnológico Superior de Naranjos for the support and facilities provided.

\section{Conclusions}

This research work highlights improvements made to the stages of a process loading goods from the shipping area or departures to the units for transport and that; In addition, this process was carried out without constant supervision, generating some negative effects such as leaving empty spaces within the units, risking the safety of the products during the transfer, thus impacting productivity, making it difficult to achieve the objectives established in the company. Nevertheless;

This demands constant improvement, optimization and updating of processes, to achieve highly the from positive and with great benefits for the company, offering better customer service as well as operating costs, for this case study, it was possible to improve with the support of simulations in AutoCAD, the loading of the goods in the unit, by taking and recording of times in each stage of the process, knowing the specific characteristics of the merchandise, its volumetric measurements, involving the personnel in charge of carrying it out, managing to increase the load capacity of the unit by $14 \%$ from 600 to 682 boxes of merchandise, by means of a rearrangement of these, while in the recording of the times occupied in carrying out the stages of the process executed with supervision, an optimization of this was obtained in 1 hour and 40 minutes (21\% less), with respect to the time carried out habitually.
Although in this study, all the information used was useful, applying it to a specific process and taking into account the stages involved, in subsequent studies the characteristics of each company should be considered, although there is common information in them; since not all handle the same processes with the same similarity, so that this contributes to continuous improvement, optimizations, and adjusting the loading maneuvers that they carry out.

\section{References}

[1]. Escudero Serrano, M. J. (2019). Logística de almacenamiento 2. Ediciones paraninfo, SA.

[2]. Espinoza Robles, L. E. (2020). Análisis de los riesgos asociados a la manipulación de mercancías y las medidas de seguridad para evitar incidentes logísticos.

[3]. Ferrer, M., Ariza, Y., Martínez, J., Garizao, J., \& Pulido-Rojano, A. (2019). Modelo de optimización colaborativo para la minimización de los costos variables de transporte de carga por carretera en Colombia. Investigación y desarrollo en TIC, 10(1), 26-36.

[4]. González, M. J. S. (2018). Optimización de la cadena logística. COML0210. IC Editorial.

[5]. Guzmán, G. C., \& Serrato, R. B. (2018). Desarrollo De Un Método De Cubicaje Para Una Pyme En El Sur De Guanajuato. Jóvenes En La Ciencia, 4(1), 1438-1443.

[6]. Jiménez Castillo, J., Bueno Solano, A., Jiménez Sánchez, J. E., \& Cedillo Campos, M. G. (2015). Cubicaje y su efecto económico en el costo logístico del transporte y competitividad empresarial. Publicación Técnica, (440).

[7]. Laza, C. A. (2019). Preparación de pedidos. MF1326. TUTOR FORMACIÓN.

[8]. Maraví, G., Matuk, D., \& Chong, M. (2019). Impacto de la infraestructura en las operaciones logísticas. Gestión de carga y entrega de mercancías. Memoria Investigaciones en Ingeniería, (17), 31-46. 
[9]. Oleas-Lara, C. X., Mazón-Fierro, G. J., \& Carrasco-Zárate, E. D. (2020). Optimización del proceso logístico en el transporte y las operaciones de exportación mediante fórmulas matemáticas en los KPI's. Dominio de las Ciencias, 6(3), 756-773.

[10]. Soto Correa, H. A., \& Rivadeneira Naranjo, N. Y. (2019). Plan logístico de transporte de carga contenerizada para la Empresa Transcarprimen SA (Bachelor's thesis, Guayaquil: ULVR, 2019.). Lévano Lévano, M. E. (2021). Propuesta de mejora del proceso de mantenimiento en un taller mecánico, aplicando la metodología de Mantenimiento Productivo Total para incrementar la productividad en una empresa de transporte urbano.

[11]. Tebelán Virula, H. E. (2021). Reducción de condiciones inseguras y optimización de los procesos para los departamentos de mantenimiento en una empresa de transporte con base en un sistema de gestión de calidad (ISO9001: 2015) (Doctoral dissertation, Universidad de San Carlos de Guatemala).

[12]. Carrasco Capcha, N. R. F. (2021). Propuesta de desarrollo e implementación de un aplicativo móvil para el proceso de monitoreo y seguimiento de unidades de transporte de carga por carretera a fin de mejorar el nivel de servicio en la empresa Inversiones Moy SAC.

[13]. Cárdenaz, R. C., Hernández, J. V., \& Barrios, O. V. (2021). Modelo administrativo y operativo para Mí Pymes transportistas de carga federal de Lázaro Cárdenas, Michoacán, que coadyuve en su competitividad. Informes de Investigación. IIATA., 6(6), 3-21.

[14] Bautista Guicha, M. L., \& Cely Martínez, Y. A. (2021). Modelo Logístico para optimizar los costos del acero Crudo al ser transportado a la Empresa Ternium Colombia SAS. 